\title{
Puritanism and Its Controversies in Nathaniel Hawthorne's The Scarlet Letter
}

\author{
Tiffany E. Pelleng, Tini Mogea, Mister Gidion Maru
}

\begin{abstract}
Puritanism is one of the phenomena contained within the literary work. Arthur Dimmesdale and Hester Prynne the main character in The Scarlet Letter by Nathaniel Hawthorne represents the puritanism condition. This research is focused on Puritanism. The research is aimed at finding out the Puritanism in The Scarlet Letter. The source of data of the research is a novel by Nathaniel Hawthorne entitled The Scarlet Letter. The main data were taken from the source of data that implied Puritanism. The main data were analyzed based on the supporting data which were taken from books, articles, essays, critics, and other related writings. The research was a descriptive qualitative library research. The researcher will use the genetic structuralism approach to find out the Puritanism.
\end{abstract}

Keywords : Puritanism, Total Depravity, Unconditional Election, Limited Atonement, Irresistible Grace, Perseverance of the Saints, Public Humiliation, Public Judged, Public Pressure.

\section{INTRODUCTION}

Puritanism is quite rarely discussed in this era because Puritanism was a religious reform movement in the late sixteenth century. The phenomena of Puritanism have inspired many writers to create a literary works. One of whom is Nathaniel Hawthorne. The majority of Hawthorne's work take America's Puritan past as its subject, but The Scarlet Letter uses the material to greatest effect. This novel displays the great impact of Puritanism on people's life and thought. Hawthorne shows the Puritan town and characters who are deeply influenced by Puritanism. In Puritan communities, whoever commits a sin will be punished.

Puritanism has influence not just the religious aspects but also the social, culture, education and politic. It also has impact in Hawthorne's backround as a decendant of Puritan figure to lead him present the sophostication of Puritan society which 
subsequently results pictures of the complexity of Puritan New England in 17th century as seen in The Scarlet Letter.

Based on the fact of the Puritans were protestant reformers who originated in England, later spread to the American colonies of New England. And their goal was to "purify" religion and politics of corruption. But, the other side this novel tells something different, the puritans who wants to reform and purify the religion become cruel to the sinner. They judge every person who commits a sin.

\section{METHODOLOGY}

This research is qualitative research. According to Bogdan and Biklen (1982) state that Qualitative research is descriptive. The data collected are in the form of words or pictures rather than numbers. The written result of the research contains quotation from data illustrate and susbtantiate presentation. (1985:30)

The writer uses two kinds of sources in collecting the data. They are primary source and secondary source. The primary source is the literary work itself, in this case The Scarlet Letter. The secondary source include the article, the data from encyclopedia and some other references that related with the novel and title to support this research.

To analyze the data the writer uses Mimetic Approach, as what Abram (1997) states that, "The mimetic orientation the explanation of art as essentially an imitation of aspects of the universe was probably the most primitive aesthetic theory." (8)

This approach means that the literary work as the imitation of the real, so in analyzing it the writer will reveal the work through the social and historical background as the important aspect of the work.

\section{DISCUSSION}

Puritan Doctrines of T.U.L.I.P.

Puritan religious doctrines are mostly based on Calvinism, the doctrine is T.U.L.I.P. Total Depravity, Unconditional Election, Limited Atonement, Irresistible Grace, and Perseverance of the saints. In novel The Scarlet Letter, doctrine T.U.L.I.P is clearly shows in the clergymen and Hester's life as the main character. The doctrines has influence the entire life of the Puritan. The writer will analyze 5 points of Puritan 
beliefs, they are: Total Depravity, Unconditional Election, Limited Atonement, Irresistible Grace, and Perseverance of the saints.

\subsubsection{Total Depravity}

Total Depravity also called total inability or total corruption. It the one of 5 points of Puritan religious beliefs. The doctrine understands it is a consequence of the fall of man, every person born into the world is morally corrupt, enslaved to sin and is apart from the grace of God. Related to the bible: For all have sinned, and come short of the glory of God (Rom. 3:23), every imagination of the thoughts of his heart was only evil continually (Genesis 6:5), in sin did my mother conceive me. (Psalms 51:5), There is no man who does not $\sin (1 \mathrm{Kings} 8: 46)$.

Throughout the novel itself, Hawthorne refers to Hester's sin as her total depravity. It's seen in the quotation bellow.

....Thus the young and pure would be taught to look at her, with the scarlet letter flaming on her breast, - at her, the child of honorable parents, - at her, the mother of a babe, that would hereafter be a woman, - at her, who had once been innocent, — as the figure, the body, the reality of $\sin . .$. (The Scarlet Letter 79).

According to the novel, Hester was described as a sinner. On the early part of the novel, the all people shows their rejection to Hester. Hester makes a scandal by birth to a daughter in the absence of her husband. Hester became a symbol of sin. Whoever that look at her will look a figure of sinner. Just like Eve who fell into sin, so does Hester Prynne. When she fell into adulterers, her entire life also fell into sin.

\subsubsection{Unconditional Election}

Unconditional Election is the doctrine which states that God chose those whom he was pleased for glory and whom for damnation (스. 9:15,21). In other word, the election is not oriented to the choice of individuals for salvation. Calvin's Institutes states, "All are not created on equal terms, but some are preordained to eternal life, others to eternal damnation; and, accordingly, as each has been created for one or other 
of these ends, we say that he has been predestinated to life or to death". Shortly, it concerns the Father's predetermination that all people who meet His conditions would live eternally in heaven and all who refuse submission to those conditions would suffer eternal damnation.

In the novel, unconditional election was clearly shown in Hester's life. From the beginning Hawthorne shows how miserable is she. It starts when she was sent by her husband to Boston, she was committed adultery, and then pregnant and had a child. She was put in jail, to be judged in front of people and lives under pressure. A bright red "A" also embroidered on her chest. Hester's story is very different from other stories, from beginning until the end, there are so many miseries in her life. It seems that the author tries to show Hester as a real picture of created for damnation. It's viewed by the quotation bellow.

Every gesture, every word, and even the silence of those with whom she came in contact, implied, and often expressed, that she was banished, and as much alone as if she inhabited another sphere, or communicated with the common nature by the organs and senses than the rest of human kind. She stood apart from moral interests, yet close beside them, like a ghost that revisits the familiar fireside, and can no longer make itself seen or felt; no more smile with the household joy, nor mourn with the kindred sorrow; or, should it succeed in manifesting its forbidden sympathy, awakening, only terror and horrible repugnance. (The Scarlet Letter 84).

This point are describing Hester's conditions. Hawthorne's explicitly shows that Hester was very lonely. Because of her sin, she was isolated by the social people and stood apart from moral. As the punishment, she lives with no communication and sympathy from other people, she lives far away from smile and joy. There's only terror and horrible repugnance. This means that, she was created for damnation. With no happiness at all, Hester has been determined to suffer and be humiliated.

\subsubsection{Limited Atonement}

The doctrine of Limited Atonement is a natural outgrowth of the doctrine Unconditional Election. At this novel, the author Nathaniel Hawthorne wants to make it 
clear that Hester's life as an important figurative symbol that represents the perfect picture of damnation. She was created as the people who are not chosen by God.

According to the novel, Hester Prynne struggles with her knowledge of her sin. She knows her actions have fallen short of both God's. By this novel, Hawthorne makes the standard of heaven more clearly. By the words of Robert Chillingworth, the author wants to clarify how Hester's character far from the Puritans standard for the doctrine Limited Atonement, “...And saintly men, who walk with God on earth, would fain be away, to walk with him on the golden pavements of the New Jerusalem". (The Scarlet Letter 126). This indicates, the standard for the salvation only for the saintly men who lives in God on earth. Hester as adulterers who commits with sin is clearly far away with the salvation.

\subsubsection{Irresistible Grace}

One of some basics of Puritanism is Irresistible Grace. Puritans believed as those elected to damnation can do nothing about it, those who are elected to salvation can do nothing to resist. God offers to all people the gospel message. This is called the external call. But to the elect, God extends an internal call and it cannot be resisted. Some of the verses used in support, it is not of him who wills nor of him who runs, but of God who has mercy (Rom. 9:16), all that the Father gives Me shall come to Me, and the one who comes to Me I will certainly not cast out (John 6:37).

According to the novel, Irresistible Grace was clearly shows by the words of clergymen.

...God knows; and He is merciful! He hath proved his mercy, most of all, in my afflictions. By giving me this burning torture to bear upon my breast! By sending yonder dark and terrible old man, to keep the torture always at red-heat! By bringing me hither, to die this death of triumphant ignominy before the people! Had either of these agonies been wanting, I had been lost forever! Praised be His name! His will be done! Farewell!" (The Scarlet Letter 269).

This quotation clearly states that the clergymen believed all things that he felt is came from God. However, he saw the pain, shame, misery, and torture as the mercy of God. He cannot reject the all pain. He knows as the elected of damnation he can do 
nothing. At the end of his life, he praise God. This indicates that God has a great power of every people and he has the power to make everything. The grace of God overwhelms people in such a way that even if they wanted to they could not repel it.

\subsubsection{Perseverance of the saints}

Perseverance of the saints is the doctrine about God's providence always follows the chosen man not matter what. By this doctrine, the salvation cannot lose. Because the Father has elected, the Son has redeemed, and the Holy Spirit has applied salvation, the elected saved are eternally secure. Some of the verses for this position are where Jesus said His sheep will never perish (John 10:27-28), where salvation is described as everlasting life (John 6:47), where it is said we have passed out of judgment (Rom. 8:1), where God promises to never let us be tempted beyond what we can handle(1 Corinthians 10:13), and where God is the one being faithful to perfect us until the day of Jesus' return (Phil. 1:6).

In this novel, the author Nathaniel Hawthorne wants to show Mr. Dimmesdale as the clergymen is the chosen man. He believes the God's will, and he knew the eternal state will be his home in heaven.

......The people look for great things from you; apprehending that another year may come about, and find their pastor gone."

"Yea, to another world," replied the minister with pious resignation.

"Heaven grant it be a better one, for; in good sooth, I hardly think to tarry with my flock through the flitting seasons of another year!.... (The Scarlet Letter 235-236).

Arthur Dimmesdale has a conversation with Roger Chillingworth. By this conversation Roger said that many people look a great thing from the clergymen. But the clergymen was knew that he has no another year, he knew well that he will go to another world that is heaven. This means that no matter how bad his life, or how much his sins, he will able to heaven. It's clearly shows how God's providence ensure his entire life.

\subsection{Controversies around the Puritan Teaching}

Looking back at historical background, controversy cannot be separated with Puritan's life. From the beginning, Puritan has built because there are people who wants to purify the faith from politics in church. So it is no wonder if the controversy is 
something familiar in the puritans. There are some controversies in Puritans social life, they are: Public Humiliation, Public Judged, Public Pressure.

\subsubsection{Public Humiliation Scarlet letter}

According to the history, in the beginning of the novel people shows their rejection to the sinner. For Puritan, purity is the important point. As stated in the Bible, Puritans believed there's no communion between light and darkness (Corinthians 2:14). It is why all people really hate Hester Prynne because her sin.

According to the novel, Puritans do the same thing to Hester. She must use the marks that indicated her as a sinner. It seen in the quotation bellow.

"What do we talk of marks and brands, whether on the bodice of her gown, or the flesh of her forehead?" cried another female, the ugliest as well as the most pitiless of these self-constituted judges. "This woman has brought shame upon us all, and ought to die. (The Scarlet Letter 51).

Hester was pregnant in the absence of husband. It is made the all people suspect that she is guilty of adultery. For them, she was brought shame to all people. Because of this, they want to give a mark or brand that indicate her as adulterer. The marks is scarlet letter A, which mean Adulterer.

\subsubsection{Public Judgement}

In Puritans life, Public judgement is the other way to punish the sinner it is not only hurtful but affected the people in a psychological way. Public judgement is the other way that Puritan choose, where they want to gather the all people to show the sinner in a podium, where everyone could see them and criticize them. Hester as adultery must be in disgrace in front of the general public to be judged because of her sin. It's reflected in quotation below.

"Hearken unto me, Hester Prynne!" said the voice.

It has already been noticed, that directly over the platform on which Hester Prynne stood was a kind of balcony, or open gallery, appended proclamation were wont to be made, amidst an assemblage of the magistracy, with all the ceremonial that attended such public observances in those days. (The Scarlet Letter 64). 
According to the quotation above, Hester faced in front of many people to be judge. She was standing in the balcony where the all eyes on her. Hester was brought in front of many people, they used the big place to make sure the all people can enter and look at her. This quotation clearly shown Hester alone was judged by many people. It's clearly hurtful and affected her psychological. It succeed makes her ashamed.

\subsubsection{Public Pressure}

In Puritan's life, there are another consequence of the sin. It is who are committed sins will be under pressure. It is the one of several consequences that the sinner should receive. This consequence not only because doubt but also to bring up the truth because Hester did not want to disclose the identity of the man who had impregnated her. Under pressure often used by the social people to push the individual to expose the truth. It is viewed in this quotation.

"Woman, transgress not beyond the limits of heaven's mercy!" cried the Reverend Mr. Wilson, more harshly than before. "That little babe hath been gifted with a voice, to second and confirm the council which thou hast heard. Speak out the name! That, and thy repentance, may avail to take the scarlet letter off thy breast." (The Scarlet Letter $68)$.

Hester as adulterers was judged to reveal the identity of the baby's father. The all people want to know who is he. It is why the reverend was cried to her, he wants to make Hester be under pressure so she can reveal the identity of the father. This indicates the controversy where Puritans used pressure as the weapon to reveal the truth.

Conclusion

Having analyze Nathaniel hawthone's The Scarlet Letter, it is clear that Hawthone has clearly drawn how puritan in other point of view. The writer found out that Puritanism has influenced many things. Hester Prynne who are the main character shows how the Puritans treat the sinners. According to the history, the author, Nathaniel Hawthorne express his criticism about Puritan's life by showing it in some controversy in the novel. Hester as adultery must be in disgrace in front of the general public to be ashamed and the scarlet letter is other consequence of the sin. The other controversy is the judgment actually coming from the church-member, they make the sinner live under 
pressure. So, Hester lived in shame and pain. The same thing also happened to Arthur Dimmesdale's life. The entire of his life, he lived in pain, regret, and guilt. Therefore, the writer concludes the Puritanism is responsible to the making of Nathaniel hawthone's The Scarlet Letter.

\section{BIBLIOGRAPHY}

Bogdan R.C. and Biglen S.K. Qualitative Research for Education $2^{\text {nd }}$ ed. Boston Allyn and Bacon, Inc. 1992

Endraswara, Suwardi. Metodologi Penelitian Sastra. Yogyakarta: Media Pressindo. 2008

Griffith, Kelley. Writing Essays about Literature. Washington. D.C.: Hortcout Brace Javanovich Publisher. 1965

Hawthorne, Nathaniel. The Scarlet Letter. New York: Dover Publication Inc. 1994

Puritanism. Encyclopedia Britannica 2009 Student and Home Edition. Chicago. Encyclopedia Britannica. 2009. 
